Free Speech versus Religious Feelings, the Sequel: Defamation of the Prophet Muhammad in E.S. v Austria

Non Peer-reviewed author version

SMET, Stijn (2019) Free Speech versus Religious Feelings, the Sequel: Defamation of the Prophet Muhammad in E.S. v Austria. In: European Constitutional Law Review, 15 (1), p. 158-170.

DOI: $10.1017 / \mathrm{S} 157401961900004 \mathrm{X}$

Handle: http://hdl.handle.net/1942/28438 


\title{
Free Speech versus Religious Feelings, the Sequel: Defamation of the Prophet Muhammad in E.S. v Austria
}

\author{
Stijn Smet
}

In E.S. v Austria the European Court of Human Rights (Strasbourg Court or Court) has ruled, not for the first time, ${ }^{1}$ that Austria can legitimately curb free speech to protect the religious feelings of believers. ${ }^{2}$ The applicant in E.S. intimated, during seminars she gave on Islam, that the Prophet Muhammad was a paedophile. The Austrian courts subsequently found her guilty of the criminal offense of publicly disparaging, in a manner capable of arousing justified indignation, a person (Muhammad) who is an object of veneration. ${ }^{3}$ In E.S., the Strasbourg Court endorses the Austrian courts' reasoning and rules that the applicant's freedom of expression has not been violated.

The Strasbourg Court has received ardent criticism in some media and the blogosphere for its judgment in E.S. ${ }^{4}$ Marko Milanovic, in particular, has castigated the Court for giving 'its blessing to the criminalization of blasphemy, in all but name'. ${ }^{5}$ Milanovic even warns that E.S. '[leads] us not to a slippery slope of a further erosion of free speech, but to a cliff'. ${ }^{6}$ The harsh nature of this criticism, verging on shock and dismay, can be understood in the context of a secularised Europe in which blasphemy laws are often considered unacceptable impediments to free speech. Most European countries, especially in Western Europe, have moved away from intolerance of blasphemy (ie. enforcement of criminal blasphemy laws), often via a period of tolerance of blasphemous speech (ie. deliberate non-enforcement of blasphemy laws), but eventually to full acceptance of speech that is critical of or ridicules religion (ie. abolition of blasphemy laws). ${ }^{7}$

\footnotetext{
1 ECtHR 20 September 1994, Case No. 13470/87, Otto-Preminger-Institut v Austria (henceforth: OttoPreminger).

${ }^{2}$ ECtHR 25 October 2018, Case No. 38450/12, E.S. v Austria.

${ }^{3}$ Art. 188 Criminal Code (Austria).

${ }^{4}$ See, among others, G. Wood, 'In Europe, Speech Is an Alienable Right', The Atlantic, 27 October 2018, www.theatlantic.com/ideas/archive/2018/10/its-not-free-speech-criticize-muhammad-echr-ruled/574174, visited 20 December 2018; E. Bougiakiotis, 'E.S. v Austria: Blasphemy Laws and the Double Standards of the European Court of Human Rights', UK Constitutional Law Blog, 22 November 2018, ukconstitutionallaw.org/2018/11/22/emmanouil-bougiakiotis-e-s-v-austria-blasphemy-laws-and-the-doublestandards-of-the-european-court-of-human-rights, visited 20 December 2018; M. Milanovic, 'Legitimizing Blasphemy Laws Through the Backdoor: The European Court's Judgment in E.S. v. Austria', EJIL:Talk!, 29 October 2018, www.ejiltalk.org/legitimizing-blasphemy-laws-through-the-backdoor-the-european-courtsjudgment-in-e-s-v-austria, visited 20 December 2018.

${ }^{5}$ Milanovic, supra n. 4.

${ }^{6}$ Ibid.

${ }^{7}$ Ireland recently made the move from tolerance to acceptance of blasphemous speech. In a 26 October 2018 constitutional referendum, the country's population voted to abolish the 'constitutional crime' of blasphemy in article 40.6(1) of the Irish Constitution. Article 40.6(1) reads, in relevant part, '[t]he publication or utterance of blasphemous ... matter is an offence which shall be punishable in accordance with law'. For discussion, see reference omitted for review purposes.
} 
At the same time, however, there remains a lingering consciousness of the (potential) fragility of religious tolerance in Europe. Although many blasphemy laws have been repealed, other laws and doctrines have taken their place. In many European countries, religious tolerance is no longer enforced by protecting religious texts, doctrines and figures as such. Instead, it is ensured - at least in some contexts - by protecting the religious feelings of believers about speech that offends those very same religious texts, doctrines and figures. ${ }^{8}$ The Strasbourg Court's case law reflects this shift from blasphemy bans to protection of religious feelings. On the one hand, the Court is adamant that '[religious persons] must tolerate and accept the denial by others of their religious beliefs and even the propagation by others of doctrines hostile to their faith'. ${ }^{9}$ On the other hand, however, the Court insists that 'respect for the religious feelings of believers [imposes] a duty to avoid as far as possible an expression that is, in regard to objects of veneration, gratuitously offensive to [religious believers]'. ${ }^{10}$

Yet this shift to protection of religious feelings is open to criticism, because the distinction with the blasphemy laws of old is not always easy to discern. The Strasbourg Court, in particular, has been charged with effectively endorsing blasphemy bans in repackaged form, what Milanovic calls 'blasphemy plus'. ${ }^{11}$ In this note, I argue that the Court's reasoning in E.S. is especially vulnerable to this charge. In E.S., the Court conflates the principles of its case law on the protection of religious feelings with standards from its defamation case law. This conflation results in a judgment that can be read as reasoning towards defamation of the Prophet Muhammad, rather than gratuitous offense to the religious feelings of Muslims. I will elaborate this point in due course.

I begin by discussing the original Strasbourg Court judgment on insult to religious feelings: Otto-Preminger-Institut v Austria (henceforth: Otto-Preminger). This prelude is important for at least two reasons. First, because much - but not all - of what the Court says in E.S. draws directly on Otto-Preminger. Second, since much of the scholarly lamentations on E.S. echo earlier criticism of Otto-Preminger. Having introduced the legal context in which E.S. was decided, I go on to summarize the facts, domestic judgments and Strasbourg Court ruling in E.S. itself. Afterwards, I critique the Court's reasoning in E.S. for conflating two lines of case law. This conflation generates a couple of serious problems, which have provoked justified criticism by Milanovic and others. Before concluding, I explore the possibility of a less contentious reading of E.S., cast in the language of tolerance.

\footnotetext{
${ }^{8}$ See, for instance, article 188 Criminal Code (Austria), which was applied by the Austrian courts in E.S. Article 188 reads, in relevant part: 'Whoever, in circumstances where his or her behaviour is likely to arouse justified indignation, publicly disparages or insults a person who, or an object which, is an object of veneration of a church or religious community established within the country [...] shall be liable to up to six months' imprisonment or a day-fine for a period of up to 360 days [emphasis added].' In E.S., the Austrian courts interpreted the reference to justified indignation as equivalent to the Strasbourg Court's emphasis on offense to religious feelings.

${ }^{9}$ E.S., supra n. 2, para. 42; Otto-Preminger, supra n. 1, para. 47.

${ }^{10}$ The citation combines E.S., supra n. 2, para. 43 and Otto-Preminger, supra n. 1, paras. 47 and 49.

${ }^{11}$ Milanovic, supra n. 4.
} 


\section{The Origin Story: Otto-Preminger-Institut v Austria}

Those less familiar with Strasbourg case law might have guessed differently from the outrage over E.S. in the blogosphere and media, but E.S. is not an isolated or 'fluke' judgment. ${ }^{12}$ Instead, it fits rather snugly in a line of Strasbourg case law on 'offense to religious feelings' that is over two decades old. The origins of this case law reside in another judgment against Austria, the 1994 Otto-Preminger. ${ }^{13}$ In this case, the Court ruled for the first time that European states could legitimately curb free speech to protect the religious feelings of believers. In Otto-Preminger, the Austrian courts had invoked article 188 of the Criminal Code to justify seizure of the film Das Liebeskonzil, for insulting the religious feelings of Roman Catholics. Das Liebeskonzil shows a performance of the play by the same name and reconstructs the 1895 blasphemy trial of its author, Oskar Panizza. Play and film portray God as a senile old man, the Virgin Mary in erotic tension with the Devil, and the adult Jesus Christ as a low grade mental defective. ${ }^{14}$ In reviewing the seizure of the film, the Strasbourg Court found no violation of freedom of expression.

In Otto-Preminger, the Court introduced a series of important novel principles to its case law. First and foremost, the Court interpreted article 9 of the Convention, which protects freedom of religion, to include a right to respect for religious feelings. ${ }^{15}$ As a result, OttoPreminger entailed a conflict between human rights. ${ }^{16}$ The Court held that in order to resolve the conflict between freedom of expression and freedom of religion, both rights had to be balanced each other. ${ }^{17}$ But rather than conduct the balancing exercise itself, the Court deferred to the rulings of the Austrian courts, since '[i]t is in the first place for the national authorities, who are better placed than the international judge, to assess the need for [measures to ensure religious peace]'. ${ }^{18}$ The Court did, however, give some guidance on how the balancing exercise ought to be conducted, chiefly by laying down the following standard:

[freedom of expression includes an] obligation to avoid as far as possible expressions that are gratuitously offensive to others and thus an infringement of their rights, and which therefore do not contribute to any form of public debate capable of furthering progress in human affairs. ${ }^{19}$

Otto-Preminger is notorious for having provoked widespread and harsh criticism. Of particular note is the near unanimity of critique, even decades later, among both opponents and proponents of proportionality analysis. ${ }^{20}$ In his scorching 2009 critique of proportionality

\footnotetext{
${ }^{12}$ E.S. is not even the first judgment about controversial statements concerning the Prophet Muhammad and Aisha. That honour belongs to I.A. v Turkey. See ECtHR 13 September 2005, Case No. 42571/98, I.A. v Turkey.

${ }^{13}$ Later important judgments in this line of case law include I.A., supra n. 12 and ECtHR 31 January 2006, Case No. 64016/00, Giniewski v France.

${ }^{14}$ The description is taken from Otto-Preminger, supra n. 1, para. 22.

${ }^{15}$ Ibid., paras. 47 and 55.

${ }^{16}$ Ibid., para. 55. On conflicts between human rights, both in general and in the case law of the Strasbourg Court in particular, see reference omitted for review purposes.

17 Otto-Preminger, supra n. 1, para. 55.

${ }^{18}$ Ibid., para. 56.

${ }^{19}$ Ibid., para. 49.

20 But see M.D. Evans, 'From Cartoons to Crucifixes: Current Controversies Concerning the Freedom of Religion and the Freedom of Expression before the European Court of Human Rights', in E.D. Reed and M.
} 
analysis, Stavros Tsakyrakis deployed Otto-Preminger to show that 'the balancing approach fails, spectacularly, to deliver what it promises'. ${ }^{21}$ Tsakyrakis argued, in particular, that the Court's judgment reveals 'an embarrassing implication of the balancing method':

if there is no such thing as a right to have one's religious feelings protected, then it makes no sense to speak of balancing in the first place, since we would be lacking that against which we are supposed to balance freedom of speech. ${ }^{22}$

George Letsas expressed similar criticism in 2012, arguing that 'the European Court's balancing methodology [in Otto-Preminger] obscures an important matter of principle', to whit the normative claim that - according to Letsas - there is no right not to be offended in one's religious feelings. ${ }^{23}$

But Otto-Preminger not only met the ire of critics of balancing. Also among proponents of proportionality, the Court's judgment did not fare well. In their 2012 book on proportionality, Matthias Klatt and Moritz Meister discussed Otto-Preminger as their single case study to illustrate everything that can go wrong in the application of the proportionality principle. ${ }^{24}$ In contrast to Tsakyrakis and Letsas, Klatt and Meister did not negate the basic premise of the Court: the case should be resolved by balancing two rights against each other. Instead, they argued that the Strasbourg Court got the balance wrong. Klatt and Meister rather aligned themselves with the different balance struck by the dissenting judges in OttoPreminger. Those three judges had ruled that the seizure of the film was disproportionate, because it was highly unlikely that those who might be offended by the film would have seen it unwittingly (among others since the cinema at which the film was to be screened catered to a relatively small public and because clear advertising meant that potential viewers were warned about the film's contents). ${ }^{25}$

Knowing this origin story of E.S. is important for at least two reasons. First, to understand that much - but not all - of what the Strasbourg Court says in E.S. is a direct application of Otto-Preminger. Second, to appreciate that much of the criticism of E.S. echoes the earlier critiques on Otto-Preminger. In his comments on E.S., Emmanouil Bougiakiotis for instance laments that the Strasbourg Court 'has never convincingly explained why the feelings of religious believers are protected under Article 9 of the Convention'. ${ }^{26}$ And

Dumper (eds.), Civil Liberties, National Security and Prospects for Consensus: Legal, Philosophical and Religious Perspectives (Cambridge University Press 2012) p. 83, p. 85 and 91 (arguing that 'the basic approach outlined by the Court [in Otto-Preminger-Institut and later judgments] has considerable merit' and 'seems to work rather well').

${ }^{21}$ S. Tsakyrakis, 'Proportionality: An Assault on Human Rights?', 7 International Journal of Constitutional Law (2009) p. 468, p. 482.

22 Ibid., p. 481.

${ }^{23}$ G. Letsas, 'Is there a Right not to be Offended in One's Religious Beliefs?', in L. Zucca and C. Ungureanu (eds.), Law, State and Religion in Europe: Debates and Dilemmas (Cambridge University Press 2012) p. 239, p. 240.

${ }^{24}$ M. Klatt and M. Meister, The Constitutional Structure of Proportionality (Oxford University Press 2012).

${ }^{25}$ Dissenting opinion of Justices Palm, Pekkanen and Makarczyk in Otto-Preminger, supra n. 1, para. 9.

${ }^{26}$ Bougiakiotis, supra n. 4. 
Milanovic claims that E.S. 'can tell us something about the dangers of proportionality as an analytical framework when it is applied without sufficient doctrinal rigor'. ${ }^{27}$

\section{The Sequel: E.S. v Austria}

As already intimated, E.S. revolved around a criminal conviction for publicly disparaging, in a manner capable of arousing justified indignation, the Prophet Muhammad. Ms. E.S., the applicant, gave seminars on Islam at the Education Institute of the far-right Freedom Party of Austria. The seminars were advertised on the Institute's website and via leaflets targeted at young voters. In the end, two seminars were held. Both were attended by around thirty participants.

In the course of the seminars, Ms. E.S. made two statements for which she would later be convicted. She first made the general claim that Muslims treat the Prophet Muhammad as an example for how to live their lives, which Ms. E.S. found problematic because she considered Muhammad's behaviour incompatible with contemporary standards and values. To buttress this point, she made a specific allegation. Referring to religious scripture, she intimated - without stating it in so many words - that Muhammad was a paedophile, since he had married one of his wives, Aisha, when she was six years old and consummated the marriage when she was nine.

Based on these statements, the Vienna Regional Criminal Court convicted Ms. E.S. under article 188 of the Criminal Code for publicly disparaging the Prophet Muhammad in a manner capable of arousing justified indignation. The court imposed a fine of EUR 480. The conviction was upheld by the Vienna Court of Appeal and the Supreme Court.

In their reasoning, the Austrian courts combined - for reasons unknown - two strands of case law of the Strasbourg Court. Much of the Austrian courts' reasoning was a direct application of the Strasbourg Court's case law on offense to religious feelings, and OttoPreminger in particular. Nothing out of the ordinary in that respect. Curiously, however, the Austrian courts also went beyond that case law by deploying concepts from the Strasbourg Court's defamation case law. In particular, they labelled the statements made by Ms. E.S. as derogatory value judgments that did not contribute to a debate of general interest. The courts held that the statements were instead intended to defame Muhammad by implying that he was not a worthy subject of worship because of his alleged paedophilia. They subsequently dedicated a sizeable portion of their reasoning to demonstrating that the allegation lacked the requisite proof. The courts emphasized that Ms. E.s. had disregarded the fact that Muhammad's marriage had continued until his death, when Aisha was no longer a minor. They also indicated that no documentary evidence existed to suggest that Muhammad's other wives or concubines had been similarly young. The Austrian courts concluded that the applicants' statements lacked a factual basis and constituted a malicious violation of the spirit of tolerance. They therefore did not enjoy the protection of freedom of expression.

\footnotetext{
${ }^{27}$ Milanovic, supra n. 4.
} 
In reviewing the Austrian courts' rulings, the Strasbourg Court says a number of predictable things with direct reference to Otto-Preminger. The Court 'reiterates that a religious group must tolerate the denial by others of their religious beliefs and even the propagation by others of doctrines hostile to their faith, as long as the statements at issue do not incite hatred or religious intolerance. ${ }^{28}$ It also references the 'duty to avoid as far as possible an expression that is, in regard to objects of veneration, gratuitously offensive to others and profane'. ${ }^{29}$ It further describes the case as involving a conflict of rights, which calls for a balancing exercise. ${ }^{30}$ And it holds that the Austrian authorities had a wide margin of appreciation in finding the right balance, because they were 'in a better position to evaluate which statements were likely to disturb the religious peace in their country'. ${ }^{31}$ The Strasbourg Court finally 'endorses' the assessment of the Austrian courts, noting that they 'extensively explained why they considered that the applicant's statements had been capable of arousing justified indignation', since these statements 'could only be understood as having been aimed at demonstrating that Muhammad was not a worthy subject of worship'. ${ }^{32}$

So far, this is all relatively straightforward application of Otto-Preminger. Had the Court only said the above, E.S. would not have made for a particularly remarkable - yet still contestable, of course - judgment. But the Court says more. It also 'agrees with the domestic courts that the impugned statements can be classified as value judgments without sufficient factual basis'. ${ }^{33}$ In doing so, the Strasbourg Court perpetuates, instead of correcting, the Austrian courts' conflation of two strands of case law. This conflation generates a couple of serious problems.

\section{Problematic Conflation of Two Strands of Case Law in E.S.}

It is important to note that the distinction between value judgments and statements of fact, as well as the concomitant standards of proof, is prevalent in the Strasbourg Court's case law. These notions are, however, commonly deployed in the Court's defamation case law. Before E.S., they had not featured explicitly in its case law on offense to religious feelings. ${ }^{34}$

Now, however, they are an overt part of that line of case law. For in E.S., the Court recalls that '[i]n its case law [it] has distinguished between statements of fact and value judgments' and repeats that 'where a statement amounts to a value judgment, the proportionality of an interference [depends] on whether there exists a sufficient factual basis for the impugned statement'. ${ }^{35}$ For both propositions, the Court cites leading judgments from

\footnotetext{
${ }^{28}$ E.S., supra n. 2, para. 52.

${ }^{29}$ Ibid., para. 43.

${ }^{30}$ Ibid., para. 46.

${ }^{31}$ Ibid., para. 50.

32 Ibid., para. 52.

33 Ibid., para. 54.

${ }^{34}$ Not in Otto-Preminger, supra n. 1, and not in the subsequent judgments of I.A., supra n. 12; Giniewski, supra n. 12; ECtHR 25 November 1996, Case No. 17419/90, Wingrove v The United Kingdom; ECtHR 2 May 2006, Case No. 50692/99, Aydin Tatlav v Turkey.

${ }^{35}$ E.S., supra n. 2, paras. 47-48.
} 
its defamation case law. ${ }^{36}$ The Court goes on to apply these standards to the case at hand. In doing so, it 'agrees with the domestic courts that the applicant must have been aware that her statements were partly based on untrue facts'. ${ }^{37}$ The Court concludes that 'the impugned statements [by Ms. E.S.] were not phrased in a neutral manner aimed at being an objective contribution to a public debate [...] but amounted to a generalisation without factual basis' ${ }^{38}$

In E.S., the Strasbourg Court thus conflates (or, less pejoratively, combines) principles from its case law on offense to religious feelings with standards from its defamation case law. The source of this conflation is easy enough to locate. Under Otto-Preminger, the Austrian courts enjoy a wide margin of appreciation. Under a more recent series of judgments, moreover, the Strasbourg Court 'would require strong reasons to substitute its view for that of the domestic courts' when 'the balancing exercise [between conflicting Convention rights] has been undertaken by the national authorities in conformity with the criteria laid down in the Court's case-law' ${ }^{39}$ Applying both principles in E.S., the Strasbourg Court defers to the reasoning of the Austrian courts. Whether deliberately or unreflectively, this deferral extends to the Austrian courts' 'borrowing' of notions from defamation law.

Yet the ensuing conflation of two strands of case law is deeply problematic. Through it, the Court effectively reduces a complex case about the difficult balance between free speech and the preservation of religious tolerance to a single factual question: is having sex with one child 1,400 years ago enough to be labelled a paedophile today? This narrow take on the case generates at least two serious problems.

First, it puts the Strasbourg Court in the awkward position - led there in the footsteps of the Austrian courts - of being compelled to investigate the truth value of religious scripture on a person who lived 1,400 years ago. Now, religious scripture surely holds truth value to adherents to the religion in question. But it should be fairly obvious that this is not the kind of truth value a court of law looks for in determining the factual basis for a value judgment. In defamation cases, the question before the Strasbourg Court is usually whether sources like government reports, confidential letters or newspaper articles provide a sufficient factual basis for the statements at issue. There is, by contrast, something distinctly alienating about the Court asking a similar question in relation to religious scripture on disputed ${ }^{40}$ events that allegedly took place some 1,400 years ago. Notions like 'truth' and 'factual accuracy' hardly seem at place here. By nonetheless investigating the 'factual basis' of Ms. E.S.'s statements, the Court comes dangerously close to - at least implicitly - interpreting religious scripture and doctrine. It thereby goes against the broadly supported scholarly position that this is not the role of secular courts. ${ }^{41}$ The Strasbourg Court moreover agrees with this position in its

\footnotetext{
${ }^{36}$ For the first proposition, the Court cites ECtHR 26 April 1994, Case No. 15974/90, Prager and Oberschlick v Austria. For the second proposition, it cites ECtHR 27 February 2001, Case No. 26958/95, Jerusalem v Austria and ECtHR 12 July 2001, Case No. 29032/95, Feldek v Slovakia.

${ }^{37}$ E.S., supra n. 2, para. 53.

${ }^{38}$ Ibid., para. 57.

${ }^{39}$ Ibid., para. 49 (citing ECtHR 7 February 2012, Case Nos. 40660/08 and 60641/08, Von Hannover v Germany (No. 2)).

${ }^{40}$ Wood, supra n. 4.

${ }^{41}$ See, for instance, A. Su, 'Judging Religious Sincerity', 5 Oxford Journal of Law and Religion (2016) p. 25; J. Martinez-Torrón, 'Fernández Martínez v Spain: An Unclear Intersection of Rights', in S. Smet and E. Brems
} 
broader freedom of religion case law, ${ }^{42}$ but arguably fails to live up to its own standards in E.S. .

Second, by reducing E.S. to a factual question - and deploying standards from defamation law to answer it - the Strasbourg Court effectively treats the case as entailing defamation of the Prophet Muhammad. As Milanovic and Bougiakiotis rightly point out, although the Court references the 'gratuitously offensive' standard from Otto-Preminger in E.S., it does not actually apply this test to the case at hand. ${ }^{43}$ Instead, the Court joins the Austrian courts in resorting to standards from defamation law. As indicated above, this is not necessarily the result of a deliberate or conscious decision. The Strasbourg Court 'simply' endorses the entirety of the Austrian courts' reasoning, since it 'would require strong reasons to substitute its view for that of the domestic courts'. ${ }^{44}$ The immediate result, however, is a judgment that is open to an entirely reasonable reading on which the central question is not one of gratuitous offense to the religious feelings of Muslims, but of defamation of Muhammad. Unsurprisingly, this invites criticism that in E.S., the Court has given 'its blessing to the criminalization of blasphemy, in all but name'. ${ }^{45}$

Before concluding, I want to suggest that E.S. is also open to an alternative, and arguably less contentious, reading in which the notion of tolerance - not that of value judgments - plays the leading role.

\section{An Alternative Reading of E.S.: The Procedural Role of Tolerance}

As is well known, arguments for religious tolerance by John Locke, Pierre Bayle and Baruch de Spinoza were central to bringing about (relatively) peaceful religious co-existence in early modern Europe. Some contemporary political philosophers insist that tolerance remains vital to ensuring peaceful co-existence in (European) societies marked by religious, cultural and ethnic diversity. ${ }^{46}$ At the same time, the salience of tolerance to law - and the law on religious freedom in particular - remains underexplored. ${ }^{47}$

The Strasbourg Court does routinely recall that '[p]luralism, tolerance and broadmindedness are hallmarks of a "democratic society". ${ }^{48}$ But the Court does not employ the notion of tolerance to resolve cases. In this, it is of course not alone. Since tolerance is

(eds.), When Human Rights Clash at the European Court of Human Rights: Conflict or Harmony? (Oxford University Press 2017) p. 192; L. Vickers, 'Freedom of Religion or Belief and Employment Law', 12 Religion \& Human Rights (2017) p. 164. For discussion in the context of US constitutional law, where this debate is particularly prominent, see R.W. Garnett, 'A Hands-off Approach to Religious Doctrine: What Are We Talking About?', 84 Notre Dame Law Review (2009) p. 837.

${ }^{42}$ See, among others, ECtHR 13 February 2003, Case Nos. $41340 / 98$ et al., Refah Partisi (The Welfare Party) v Turkey, para. 91; ECtHR 15 January 2013, Case Nos. 48420/10 et al., Eweida v The United Kingdom, para. 81.

${ }^{43}$ Milanovic, supra n. 4; Bougiakiotis, supra n. 4.

${ }^{44}$ E.S., supra n. 2, para. 49.

${ }^{45}$ Milanovic, supra n. 2.

${ }^{46}$ See, for instance, J. Horton, 'Why the traditional conception of toleration still matters', 14 Critical Review of International Social and Political Philosophy (2011) p. 289.

${ }^{47}$ For discussion, see references omitted for review purposes.

${ }^{48}$ See, for instance, ECtHR 1 July 2014, Case No. 43835/11, S.A.S. v France, para. 128. 
usually understood as a moral virtue and/or political value, courts tend to only reference it as 'background scenery' in adjudicating religious disputes. ${ }^{49}$ A notable exception is the Supreme Court of Israel. In its case law, the Israeli Supreme Court has developed a 'threshold of tolerance' test, which it uses inter alia to adjudicate cases in which free speech collides with religious feelings. ${ }^{50}$ The 'threshold of tolerance' test is, however, extremely stringent. Under it, free speech prevails 'unless the violation of religious feelings is nearly certain and their violation is real and severe'. ${ }^{51}$ The reason for the test's stringency is that, unlike the Strasbourg Court, the Supreme Court of Israel has excluded religious feelings from the scope of freedom of religion. ${ }^{52}$ Instead, it treats the protection of religious feelings as a public interest. ${ }^{53}$ And as a public interest, the protection of religious feelings occupies - within the conception of proportionality employed by the Israeli Supreme Court - a prima facie subordinate position to constitutional rights such as freedom of expression. ${ }^{54}$

I do not mean to suggest that the Strasbourg Court ought to develop the 'gratuitously offensive' standard of Otto-Preminger into a full-fledged 'spirit of tolerance' test, akin to the Israeli 'threshold of tolerance' test. Although that would give the notion of tolerance more substantive bite in the Court's case law, it would also imply an increase in the protection of free speech when it clashes with religious feelings. Much to the dismay of critics like Milanovic, the Strasbourg Court is clearly unwilling to go down this road.

Tolerance could however also play a more robust procedural role in the resolution of cases involving offense to religious feelings. ${ }^{55}$ The Court's judgment in E.S. is arguably open to a reading - if we ignore the misconceived reliance on defamation law - on which tolerance plays precisely this role. In E.S., the Court first holds that where 'expressions go beyond the limits of a critical denial of other people's religious beliefs and are likely to incite religious intolerance', states may (not must) consider such expressions incompatible with freedom of religion. ${ }^{56}$ The Court goes on to note that 'Article 188 of the [Austrian] Criminal Code [aims] at the protection of religious peace and tolerance'. ${ }^{57}$ The Court then rules that the Austrian courts enjoyed a wide margin of appreciation, because 'they were in a better position to evaluate which statements were likely to disturb the religious peace [and tolerance] in their country'. ${ }^{58}$ Finally, the Court 'endorses' - on a purely procedural argument, 'defers to' would be preferable - the Austrian courts' conclusion that the statements 'could be conceived as a malicious violation of the spirit of tolerance'. ${ }^{59}$ Here we have the broad outlines of a

\footnotetext{
${ }^{49}$ Nevertheless, as I show elsewhere, the notion of tolerance does have an impact on the interpretation of religious freedom in constitutional law. See reference omitted for review purposes.

50 See, for instance, High Court of Justice (Israel) 18 June 2001, Case No. 1514/01, Gur Aryeh v Second

Television and Radio Authority.

${ }^{51}$ Ibid., para. 6.

${ }^{52}$ High Court of Justice (Israel) 13 April 1997, Case No. 5016/96, Horev v Minister of Transportation, para. 50.

${ }^{53}$ Ibid.

${ }^{54}$ Gur Aryeh, supra n. 50, paras. 6 and 8.

55 This would be entirely in line with the 'procedural turn' in the Court's wider case law. See O.M. Arnardóttir, 'The "Procedural Turn" under the European Convention on Human Rights and Presumptions of Convention Compliance', 15 International Journal of Constitutional Law (2017) p. 9.

${ }^{56}$ E.S., supra n. 2, para. 43.

${ }^{57}$ Ibid., para. 50.

58 Ibid., para. 52.

${ }^{59}$ Ibid., para. 53.
} 
procedural reading of E.S. that avoids problematic arguments on the truth value of the statements at issue.

Admittedly, this procedural reading of E.S., centred on the notion of tolerance, is unlikely to convince the Court's critics. ${ }^{60}$ Perhaps for good reason, for one of the great difficulties with cases like E.S. remains that the curtailment of free speech is motivated by the authorities' assumptions about offense to religious feelings, rather than evidence of actual offense. And regardless of whether the Strasbourg Court engages in substantive or procedural review, assumptions hardly provide a solid basis for (drastic) curtailment of freedom of expression.

\section{Conclusion}

Irrespective of how one feels (no pun intended) about E.S., it is evident that the Strasbourg Court has backed itself into a corner with its case law on religious feelings. Otto-Preminger is generally considered bad case law. Yet the Court appears destined to repeat and even reinforce it. In the 2005 case of I.A. v Turkey, which also involved disparaging statements about the Prophet Muhammad, there appeared to be an opening for eventual overruling of Otto-Preminger. The Court decided against free speech in I.A., but only by the barest of majorities (4-3 judges). The three judges in dissent moreover argued that 'the time has perhaps come to "revisit" [Otto-Preminger]'. ${ }^{61}$

More than a decade later, however, the Strasbourg Court has again confirmed OttoPreminger, and this time unanimously. The persistence of Otto-Preminger is partly due to the wide margin of appreciation enjoyed by member states in this area of law. But the close alignment between Otto-Preminger and E.S. also played an important role. Arguably, the only major difference between both cases was the 'targeted' group. Otto-Preminger involved alleged offense to the religious feelings of the Christian majority. ${ }^{62}$ In E.S., by contrast, the supposedly offended believers were Muslims, a religious minority in an Austria that is now (though not at the time of the facts) led by a right-populist government that targets Islam. Given this constellation, distinguishing E.S. or using it as an occasion to overrule OttoPreminger would surely have opened the Court up to renewed claims of prejudice against Islam. ${ }^{63}$ This eventuality may well have been on the judges' minds when deciding E.S. . Combine this with consistent earlier case law and the workings of the (wide) margin of appreciation, and it difficult to perceive how the Strasbourg Court could have ruled differently. Although this might explain the outcome in E.S., it is hardly an excuse for poor reasoning.

\footnotetext{
${ }^{60}$ Milanovic, supra n. 4 (concluding that in E.S. 'the Court eroded the freedom of speech while doing nothing meaningful for religious tolerance').

${ }^{61}$ Dissenting opinion of Judges Costa, Cabral Barreto and Jungwiert in I.A., supra n. 12, para. 9.

${ }^{62}$ In Otto-Preminger, supra n. 1, para. 56 (read together with para. 52), the Court made a point of noting that Roman Catholics constituted $87 \%$ of the population in Tyrol (where the film was to be screened).

${ }^{63}$ See critical responses to among others S.A.S., supra n. 48; ECtHR 10 November 2005, Case No. 44774/98, Leyla Şahin v Turkey; ECtHR 15 February 2001, Case No. 42393/98 Dahlab v Switzerland.
} 